\title{
The Effectiveness of Predict-Observe-Explain Strategy to Reduce Misconception in Thermochemistry
}

\author{
Imroatuz Zakiyah \\ Department of Science Education \\ Universitas Negeri Surabaya \\ Surabaya, Indonesia \\ imroatuzzakiyah@mhs.unesa.ac.id
}

\author{
Wahono Widodo \\ Department of Science \\ Universitas Negeri Surabaya \\ Surabaya Indonesia \\ wahonowidodo@unesa.ac.id
}

\author{
Tukiran \\ Department of Science \\ Universitas Negeri Surabaya \\ Surabaya Indonesia \\ tukiran@unesa.ac.id
}

\begin{abstract}
Thermochemistry is one of materials that had low student's understanding ability on National Examination in 2013-2015 which only gets $55.45 \%$. This low percentage because of student still has misconception. Misconception can cause students having low ability to understand a concept. This misconception should be reduced, one of the ways to reduced is using remedial teaching with appropriate learning strategy which suitable with the problem that faced by student and one of them is predict-observe-explain (POE) strategy. The aim of this research is to know the effectivity of learning process using POE strategy to reduce misconceptions. This research was using One Group Pretest-Posttest Design. The sample is 33 students of XI MIA 4 at senior high school Kemala Bhayangkari 3. To know student conception this research using three tiers diagnostic test for pretest and posttest. A pretest was conducted after students have a conventional learning process with their teacher. Posttest was conducted after the student had given a treatment using POE strategy. Generally, the result shows students' changing conception. Initially, student's conception which knew the concept is $\mathbf{2 1 . 0 3 \%}$ and student with misconception is $\mathbf{5 7 . 1 2 \%}$, after implementation of the learning process using POE strategy the conception changing gradually becomes $93.5 \%$ and $4.61 \%$. So we can conclude that POE strategy effective to reduce misconception that had been experienced by student.
\end{abstract}

Keywords-POE Strategy, Misconception, Thermochemistry

\section{INTRODUCTION}

Chemistry is a material that difficult to learn. It was consistent with the results of a study that thermochemistry is a difficult topic for high school students and they have various misconceptions in it [1]. This is reinforced by preliminary study which states that $95 \%$ of students think that chemistry is difficult to learn because there are so many concepts that must be understood $(70 \%) .75 \%$ of students think that thermochemistry is a difficult material because there are many concepts in it. Only $35 \%$ of students can answer questions of concept correctly. This Low mastery of concepts is a major problem on formal education which caused low on student achievement. This is evidenced by the low score of the National Exam results in thermochemistry material from 2013-2015, which was only 55.44\%. Besides that, it was strengthened from previous research which said completeness of class on thermochemistry material only $42 \%$ so it needed to be improved [2].

One way to improve the completeness of class is by understanding and mastering a concept well. But in reality, there are many mistakes in understanding concepts or commonly called misconceptions which are the result of initial conception or preconception. Misconception is a conception of someone which is clearly different and often conflict with scientific concepts [3]. A study found that $60 \%$ of students consider all reactions to occur spontaneously as exothermic reactions; $30 \%$ of students think that heat always needed so chemical reactions can occur; $45 \%$ of students cannot determine the best fuel by considering enthalpy changes and same amount for a combustion reaction, students do not know the system of a reaction; students cannot determine the system and environment on calorimeter; many of students do not understand the enthalpy of formation [1]. Other Misconceptions on thermochemistry are found in systems and environmental concepts, concepts of exothermic and endothermic reactions, enthalpy concepts and enthalpy changes $[4,5]$. Same with the result of preliminary study which found that student has difficulties when determining system and the environment in a reaction, and also student got difficulties when determining exothermic and endothermic reaction, formation, and dissociation enthalpy changed and Hess law. Misunderstandings or lack of understanding of thermochemical problems are so worrying that they must be reduced [6].

One way to solve it is through a remedial teaching program. Remedial teaching is a teaching method that involves the activities of diagnosis, prevention, treatment, healing, and repairing of students' mistakes in learning process [7]. Solving problems in learning using remedial teaching is expected to be one of sources of experience for student when they are willing to improve learning, especially in student misconception remediation programs [8]. One strategy that used to eliminate misconceptions is strategy of Predict-Observe Explain (POE).

Predict-Observe-Explain (POE) Strategy has three stages as follows: 1) Predict, the teacher provides a background situation and then asks students to write down their predictions and their reasons (why it can be happen based on student beliefs); 2) Observe, students make observations, experiments, or learn about the actual situation; 3) Explain, students try to understand why their predictions are wrong and formulate a new theory to explain what happened [9]. This strategy can minimize the occurrence of student misconceptions compared with conventional learning [10]. In addition, the POE strategy provides a better process on teaching concepts so it can help student to gain a better understanding of a concept and also can reduce conceptual errors on students [11]. Positive effects of teaching with POE 
strategies that students can overcome misconceptions and improve their learning outcomes [12].

Since the POE strategy can minimize misconceptions, it will be very interesting if the researcher uses the POE strategy to overcome misconceptions in the thermochemistry material which suffered by students. Because so far the POE strategy is only used to reduce misconceptions in physics and biology and misconceptions on thermochemistry are reduced using cognitive conflict and conceptual change strategy. Unfortunately, there are still no studies using POE strategy to reduce misconceptions in thermochemistry. So the purpose of this study was to determine the effectiveness of the POE strategy on reducing misconceptions in thermochemistry.

\section{METHOD}

This study uses One Group Pretest-Posttest Design. This research was conducted on class XI MIA SMA Kemala Bhayangkari 3 Porong students. The sample in this study were 33 students of class XI MIA 4 of SMA Kemala Bhayangkari 3 Porong. All students were divided into 6 heterogeneous groups. First students were given a conceptual understanding test as pretest to know student conception status. Then remediation is given by using worksheet with POE strategy. At the end of the study, students were given conceptual understanding test as posttest to determine changes in conception status. The results then analyzed using the Wilcoxon signed-rank test.

The conceptual understanding test in posttest and pretest is a diagnostic test which is composed of three levels. The first level contains multiple-choice tests, the second level contains several alternative reasons related to the first tier, the third level is confidence rating that can measure the level of students' confidence in the answer which contains two options namely sure and unsure [13]. This test contains 20 questions divided into 3 concepts which are exothermicendotherms, formation, and dissociation enthalpy changes and Hess law. The data that obtained gave students' conception status which written in Table I:

TABLE I. ClassifiCATion OF StUdent Status

\begin{tabular}{|c|c|c|c|c|}
\hline \multicolumn{3}{|c|}{ Student Response } & \multirow{2}{*}{ ategory } & \\
\hline $\begin{array}{l}\text { irst Tier) } \\
\text { Answer }\end{array}$ & $\begin{array}{l}\text { pnd Tier) } \\
\text { eason }\end{array}$ & $\begin{array}{l}\text { rd Tier) } \\
\text { nce Rating }\end{array}$ & & \\
\hline \begin{tabular}{|l|} 
True \\
\end{tabular} & True & Sure & w Concept & \\
\hline True & True & nsure & $\begin{array}{l}\text { (Lucky Concept } \\
\text { (Luess) }\end{array}$ & \\
\hline True & False & nsure & Know Concept & \\
\hline False & True & nsure & Know Concept & \\
\hline False & False & nsure & Know Concept & \\
\hline True & False & Sure & $\begin{array}{c}\text { ception (false } \\
\text { positive) }\end{array}$ & \\
\hline False & True & Sure & $\begin{array}{r}\text { ception (false } \\
\text { negative) }\end{array}$ & \\
\hline False & False & Sure & conception & \\
\hline
\end{tabular}

\section{RESULT AND DISCUSSION}

The pretest and posttest data describe conceptual understanding of students which categorized in conceptions status of Know Concepts, Don't Know Concepts and Misconceptions. Comparison of Pretest and Posttest results is presented in Figure 1.

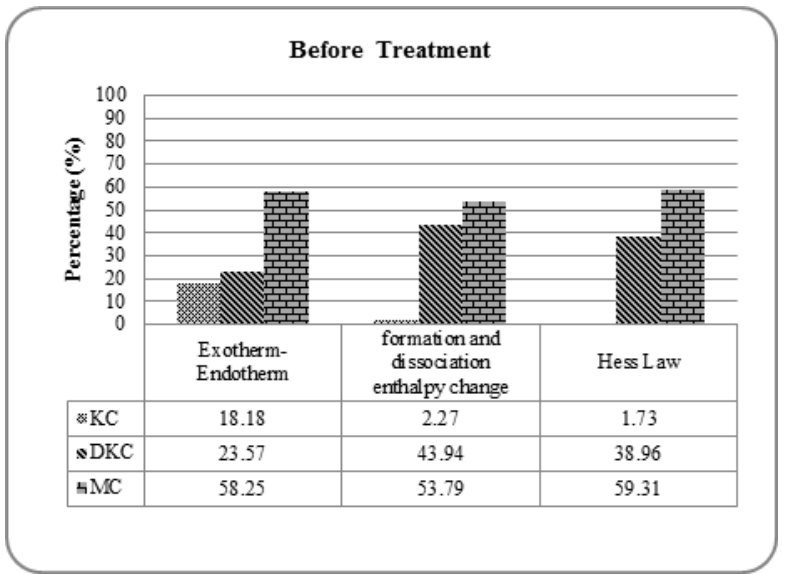

Fig 1. Student's conception status on each concept before treatment using POE strategy

Student's conception before treatment using the POE strategy is shown in Figure 1. This initial condition is used to show that the conceptual understanding of students on knowing the concept is still small, which is equal to $18.18 \%$ in the concepts exotherm and endotherm; $2.27 \%$ in the concept enthalpy changes and decomposition; and $1.73 \%$ in Hess's law with average $21.03 \%$. Students tend on misconceptions with successive percentage is $58.25 \%$; $53.79 \%$; and $59.31 \%$ with an average of $57.12 \%$. Misconceptions that occur can be reduced even though it requires a long process. If the misconceptions that occur in students are left, it will undermine students' understanding of chemistry. Because we know that most of chemistry concepts are interrelated. Misconceptions that occur must be reduced so that understanding and mastery of concepts increase that shown by higher learning outcomes. So it requires improvement in learning so that the concepts in that material can be mastered by students properly and correctly.

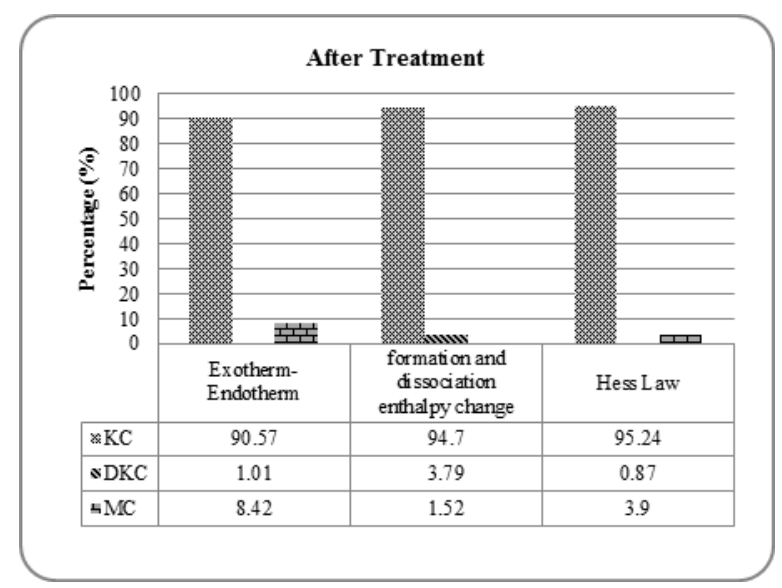

Fig 2. Student's conception status on each concept after treatment using POE strategy

One of remedial learning that used to overcome misconceptions is learning by using predict-observe-explain strategy. Figure 2 shows student's conception after treatment using POE strategy. On the student's final test there was a significant increase in student conception, the students' initial understanding which initially had misconception and did not know the concept was well understood so it changed become know the concept. The number of students who know the concept increases on three concepts with successive 
percentage of $90.57 \% ; 94.7 \%$; and $95.24 \%$ with an average $93.5 \%$. The indicator of successful learning of POE strategy learning can be seen by increasing students' conception conditions percentage. It means that the misconceptions experienced by students decrease. It indicated that after learning has done, student's understanding of concepts increases. This is the impact of learning that is to improve and strengthen student's concept in the construction of knowledge to form new concepts which are in accordance with scientific concepts [14]. It supported the statement of learning process with POE strategies that can make misconceptions that occur in student decreases $[15,16]$.

In addition [12] learning with POE strategies can help in overcoming misconceptions experienced by students because learning using POE strategies can develop the ability to track their initial knowledge and they can find out what is lacking and misconceptions so that they can correct the misconceptions or imperfect learning earlier [11].

The first stage of learning using POE Strategy is predict. At this stage, the teacher will understand how the students' concepts and initial thoughts about the problem posed. In this prediction process, the teacher can also understand the student's misconceptions. This is important for the teacher in helping students to build the correct concepts. The second stage, observe, enables cognitive conflict problems. Cognitive conflict approaches and interesting situations are factors that influence students' conception changes [17]. The third stage is explain. If the prediction results are in accordance with the results of observations and after they get an explanation of the truth of their predictions, students are more confident in the concept. However, if the assumptions are not fixed then students can look for explanations about the inaccuracies in their predictions.

Students will experience changing their concepts from an incorrect concept to the correct concept. At this stage, students learn from mistakes so they are not easily forgotten. The third stage provokes student-student and student-teacher discussion. At this stage the results of the experiments and the literature studies they conducted were presented to be compared with the results of other groups. At the time of the discussion, each group usually has a different conclusion from the data generated. The process that occurs at the third stage also develops student reasoning. Students are easier to build understanding if they can communicate their ideas to other students or teachers. Also at this stage helps encourage students to obtain and understand their own knowledge that stems from their own ideas.

Furthermore, the existing data were analyzed using the Wilcoxon signed-rank test with a confidence level of $95 \%$ which is used to prove that exists or not the effect of learning by using POE strategy on changing student conception status and giving results such as shown in Table II.
TABLE II. RESUlt OF WILCOXON SIGNED RANK TEST

\begin{tabular}{|c|c|c|c|c|c|}
\hline \multicolumn{6}{|c|}{ Ranks } \\
\hline & & & $\mathrm{N}$ & $\begin{array}{l}\text { Mean } \\
\text { Rank }\end{array}$ & $\begin{array}{l}\text { Sum of } \\
\text { Ranks }\end{array}$ \\
\hline \multirow{4}{*}{$\begin{array}{r}\text { MKPOSTMIA4 } \\
\text { MKPREMIA4 }\end{array}$} & \multicolumn{2}{|c|}{ Negative Ranks } & $20^{\mathrm{a}}$ & 10.50 & 210.00 \\
\hline & \multicolumn{2}{|c|}{ Positive Ranks } & $0^{\mathrm{b}}$ & .00 & .00 \\
\hline & \multicolumn{2}{|c|}{ Ties } & $0^{\mathrm{c}}$ & & \\
\hline & \multicolumn{2}{|c|}{ Total } & 20 & & \\
\hline \multicolumn{6}{|c|}{ a. MKPOSTMIA4 < MKPREMIA4 } \\
\hline \multicolumn{6}{|c|}{ b. MKPOSTMIA4 > MKPREMIA4 } \\
\hline \multicolumn{6}{|c|}{ c. MKPOSTMIA4 = MKPREMIA4 } \\
\hline \multicolumn{6}{|c|}{ Test Statistics $^{\mathrm{b}}$} \\
\hline & & \multicolumn{4}{|c|}{ MKPOSTMIA4 - MKPREMIA4 } \\
\hline \multicolumn{2}{|l|}{ Z } & \multicolumn{4}{|c|}{-3.928} \\
\hline \multicolumn{2}{|c|}{ Asymp. Sig. (2-tailed) } & & & & .000 \\
\hline
\end{tabular}

a. Based on positive ranks.

b. Wilcoxon Signed Ranks Test

Based on the results in Table 2, it was found that the sign 2 tailed was 0.000 this value below table value, the amount of table value is 0.05 which means that there is a change in the conception of misconception become known concept after learning using Predict-Observe Explain strategy had been done. It means that there is a significant influence on the implementation of learning with POE strategy to improve students' conceptual status as an impact of decreasing students' misconception status. It supported by research that said POE strategies can have impact on decreasing students' misconceptions because POE strategy facilitates scientific investigating phenomena in small groups, then they make predictions about these phenomena and then observe after that compare predictions and explanations they make based on observations that have been done [12]. Students eliminate cognitive conflicts that occur between predictions and observations by making explanations so that the POE strategy provides the conceptual understanding and deep learning for students [18]. In addition, learning with POE strategies can improve students 'understanding of concepts, we also found that POE strategies were effective in enhancing students' conceptual understanding $[19,20]$.

But there are still some students who experience misconceptions even though the learning process with POE strategy has been done with successive percentage of $8.42 \%$; $1.52 \%$ and $3.9 \%$ with an average of $4.61 \%$. This situation is caused by students still fixated on their initial understanding. This condition has been explained in another research that misconceptions are resistant or difficult to change and tend to persist [21]. This is in line with other opinions that misconceptions cannot be changed only with new information or students still have the opportunity to return to their original conception even though they have been introduced to the correct concept $[3,22]$. Resistance on misconception may occur due to a state of disequilibration through the process of cognitive conflict that hasn't reached equilibration state. Equilibration can occur if assimilation and accommodation happen in an integrated manner [23]. According to Renner and Lawsone equilibration can cause on development of the scheme or intellectual structure of student be more complex and more useful, so that repeated treatment 
is needed to complete students who still have misconceptions [24].

\section{CONCLUSION}

he results of the study indicate that learning by using the POE strategy successfully increases know the concept status, with an average percentage of $21.03 \%$ changed become $93.5 \%$ and reduce misconceptions which have an average percentage of $57.12 \%$ to $4.61 \%$. So it can be said that a learning process using the POE strategy effectively influences the improvement of status to know concepts and reduce misconceptions.

\section{ACKNOWLEDGMENT}

The author's gratitude to all the advisor for their continuous encouragement, kindly advice throughout this research, and also parents and colleagues who always supporting on all of aspect for this research.

\section{REFERENCES}

[1] E. Yalçınkaya, Ö. Taştan and Y. Boz, "High school students' conceptions about energy in chemical reactions," Pamukkale University Journal of Education, Vol. 26, pp. 1-11,2009.

[2] V. A. Sugiawati., "Penggunaan Strategi Konflik Kognitif Dalam Pembelajaran TPS Untuk Mereduksi Miskonsepsi Siswa Pada Materi Termokimia,” Jurnal Nalar Pendidikan, Vol. 1 No. 1, 2013.

[3] M. Ibrahim, Konsep, Miskonsepsi Dan Cara Pembelajarannya, Surabaya: Unipress Unesa, 2012.

[4] A. Sutisna, "Pengembangan Model Pembelajaran Konflik Kognitif untuk Memfasilitasi Perubahan Konseptual dan Peningkatan Keterampilan Berfikir Kritis Siswa Pada Materi Termokimia,” Tesis Tidak Dipublikasikan, Universitas Pendidikan Indonesia, 2013.

[5] I. A. N. D. Santini, "Penggunaan Pendekatan Konflik Kognitif untuk Mengatasi Miskonsepsi Pembelajaran Termokimia (Studi Kasus pada Siswa Kelas XI IA di SMA Taruna Nusantara Magelang Tahun Pelajaran 2008/2009," UPT Perpustakaan Universitas Sebelas Maret, 2009, didownload dari https://digilib.uns.ac.id/dokumen/download/5085/MTQzNzk=/Penggu naan-pendekatan-konflik-kognitif-untuk-mengatasi-miskonsepsipembelajaran-termokimia-studi-kasus-pada-siswa-kelas-xi-ia-di-smataruna-nusantara-magelang-tahun-pelajaran-20082009-abstrak.pdf accessed on August 15th 2018

[6] H. Saricayir, S. Ay, A. Comek, G. Cansiz, and M. Uce, "Determining Students' Conceptual Understanding Level of Thermodynamic," Journal of Education and Training Studies, Vol. 4, No. 6, pp. 69-79, 2016.

[7] H. G. Tarigan, Pengajaran Remedi Bahasa, Bandung: Angkasa, 2009

[8] A. Suyono, Muchlis, and P. Setiarso, "Diseminasi Model Prevensi dan Kurasi Miskonsepsi Siswa pada Konsep Kimia," Laporan Akhir Penelitian Unggulan Perguruan Tinggi Surabaya: LPPM Unesa, 2014.
[9] J. Dalziel. "Practical E-Teaching Strategies For Predict-ObserveExplain Problem-Based Learning And Role Plays,” 2010.

[10] Mursalin, "Meminimalkan Miskonsepsi Pada Materi Rangkaian Listrik Dengan Pembelajaran Predict-Observe-Explain," Jurnal Ilmu Pendidikan Universitas Negeri Malang, Vol. 20, pp.1, 2014.

[11] H. Özdemir, H. Bağ. Hüseyin, and K. Bİlen, "Effect of Laboratory Activities Designed Based On Prediction- Observation - Explanation (POE) Strategy On Pre-Service Science Teachers' Understanding Of Acid base Subject," Western Anatolia Journal of Educational Sciences (WAJES), pp. 169-174, 2011

[12] I. Kibirige, J. Osodo, and K. M. Tlala, "The effect of predict-observeexplain strategy on learners' misconceptions about dissolved salts. Mediterranean," Journal of Social Sciences, Vol.5, No.4, pp. 300, 2014.

[13] Z. D. Kirbulut, and O. Geban, "Using Three-Tier Diagnostic Test to Assess Students' Misconceptions of States of Matter," Eurasia Journal of Mathematics, Science \& Technology Education, Vol. 10 No.5, pp. 509-521, 2014.

[14] P. Suparno. "Filsafat Konstruktivisme dalam Pendidikan," Yogyakarta: Kanisius, 1977.

[15] A. C. Anam and S. S. Edie, "Penerapan Strategi Poe (Predict-ObserveExplain) Untuk Memperbaiki Miskonsepsi Fisika Pada Sub Pokok Bahasan Arus Dan Tegangan Listrik Bagi Peserta Didik Kelas X SMA Teuku Umar Semarang," UPEJ Unnes Physics Education Journal, Vol. 4, No.2, 2015.

[16] R. Lebdiana and N. Hindarto, "Pengembangan Perangkat Pembelajaran Materi Suhu Dan Kalor Berbasis POE (Predict-ObserveExplain) Untuk Meremediasi Miskonsepsi Siswa," UPEJ Unnes Physics Education Journal, Vol. 4, No.2, 2015.

[17] H. Kang, L. C. Scharmann, S. Kang. Sujin, and T. Noh, "Cognitive Conflict and Situational Interest as Factors Influencing Conceptual Change," International Journal of Environtmental \& Science Education, 5(4), 383-404, 2010.

[18] A. Seşen and A. Mutlu, "Predict-Observe-Explain Tasks in Chemistry Laboratory: Pre-Service Elementary Teachers' Understanding and Attitudes," Sakarya University Journal of Education, Vol.6, No.2, 2016.

[19] H. Rosdianto, E. Murdani, Hendra, "Implementasi Model Pembelajaran POE (Predict-Observe-Explain) Untuk Meningkatkan Pemahaman Konsep Siswa Pada Materi Hukum Newton," Jurnal Pendidikan Fisika. Vol.6, No.1, 2017.

[20] V. Anarky, A. Syuhendri, and H. Akhsan, "The Effectiveness of Poe (Predict-Observe-Explain) Based Teaching Strategy in Improving Students' Conceptual Understanding on Heat and Temperature in SMAN 9 Palembang," Proceedings of the 2nd SULE - IC. 2016

[21] H. D. Barke, A. Hazari, and S. Yitbarek, "Misconceptions in chemistry: Addressing perceptions in chemical education," Springer Science \& Business Media, 2008

[22] R. Arends, Learning to Teach, Jogjakarta: Pustaka Pelajar, 2008.

[23] Suyono and Hariyanto, Belajar dan PembelajaranTeori dan Konsep Dasar, Bandung: Rosda, 2011

[24] Effendy, "Upaya untuk Mengatasi Kesalahan Konsep dalam Pengajaran dengan Menggunakan Strategi Konflik Kognitif,” Malang: Jurnal Media Komunikasi Kimia. Vol.2, No.6, pp.1-19, 2002. 